\title{
Level of patient information on antibiotic use
}

\author{
Fernando de Sá Del Fiol", Silvio Barberato-Filho, Luciane Cruz Lopes, Maria Inês de Toledo
}

Pharmaceutical Sciences Course, Sorocaba University

\begin{abstract}
Establishing an effective antimicrobial therapeutic requires choosing the appropriate antibiotic and ensuring compliance with times and doses prescribed. Problems concerning early abandonment and unfinished prescriptions due to lack of information, as well as more resistant microorganisms, have been identified as the major factors responsible for therapeutic failure in bacterial infections. This study aimed to determine the level of information among antibiotic users undergoing treatment with these drugs, and habits related to other therapies. A survey was applied to 403 users and identified great difficulties in understanding prescriptions, especially among users with no formal schooling who understood only 21 to $28 \%$ of the prescribed instructions. This same group reported having received the lowest amount of information during the consultation, with only $28.6 \%$ receiving verbal information from the prescriber on the length of course with the drug. Additionally, $21 \%$ of this group reported a tendency to use the antibiotic until symptoms resolved, without heeding the length of course prescribed. Guidance on antibiotics use should be an integral and fundamental part of effective therapy.
\end{abstract}

Uniterms: Antimicrobial therapeutic. Antimicrobial resistance. Antibiotics/rational use.

Para se estabelecer uma terapêutica antimicrobiana eficaz, é necessário que se escolha o fármaco adequado e que este seja utilizado na dose e tempo prescritos. Abandonos precoces e o não cumprimento da prescrição, originados por falta de informação adequada, têm sido apontados, juntamente com microrganismos resistentes, como os grandes responsáveis por falhas terapêuticas no tratamento de infecções bacterianas. Este trabalho teve por objetivo conhecer o nível de informação de usuários de antibióticos sobre estes fármacos, tanto na terapêutica a que estavam sendo submetidos, quanto em seus hábitos em outras terapêuticas. Por meio de um questionário aplicado a 403 usuários, notou-se uma grande dificuldade de entendimento da prescrição, especialmente por usuários sem estudo formal, chegando a níveis de entendimento de apenas 21 a $28 \%$ das prescrições estabelecidas. Esse mesmo grupo relatou ter recebido a menor quantidade de informações durante a consulta, apenas $28,6 \%$ receberam informações verbais do prescritor sobre o tempo que deveriam utilizar o medicamento. Adicionalmente, foi percebido que $21 \%$ desse grupo informaram que têm o costume de utilizar o antibiótico até desaparecer os sintomas, sem se preocupar com o tempo prescrito. A orientação para a utilização do medicamento é parte integrante e fundamental de uma terapêutica eficaz.

Unitermos: Terapêutica antimicrobiana. Resistência bacteriana. Antibióticos/uso racional.

\section{INTRODUCTION}

Antibiotics were first brought into clinical use more than 60 years ago and remain the only treatment option available for combating bacterial infections. The irrational used of this class of drug has been the cause of increasing concern, in view of the growing number of multiresistant

Correspondence: F. de S. Del Fiol. Universidade de Sorocaba. Rua Paulo Setúbal, 344 - Cerquilho - 8520-000 Sorocaba - OS, Brasil. E-mail:fernando. fiol@uniso.br organisms which fail to respond to any pharmacological treatment (Rybak, 2006).

The scientific community has sought alternatives to resolve this issue and several strategies have been adopted, both techno-scientific and socio-educational, to control bacterial resistance. Numbering among the strategies adopted is the chemical-structural modification of preexisting antibacterial agents, research into novel targets for drugs action, vaccines, the introduction of associated drugs, and educational measures aimed at controlling antibiotic use (Del Fiol et al., 2000). 
With regard to the rational use of antimicrobials, the World Health Organization, at the $51^{\text {st }}$ World Assembly held in 1998, released a document recommending measures to combat bacterial infections and resistance. The recommendations it contained were as follows: a) to improve access to suitable antimicrobials; b) to rationalize use of anti-microbials; c) to strengthen health systems along with their ability to perform surveillance on microbiotic use; d) to ensure compliance with sanitary regulations; e) to foster research into novel drugs and/or vaccines (WHO, 1998).

It is clear that in rationalizing antibiotics, priority must be placed on the process of treatment using these medicines, from time of infection diagnosis and prescription to the dispensing and use of the drug by patients.

Several points should be considered in defining rational and effective antimicrobial treatment. Firstly, the true need for antibacterial drugs needs to be rigorously assessed, since the literature has shown numerous cases of infections whose cause is known to be viral yet were treated with antibiotics (Ladd, 2005; Marra et al., 2006).

Once the need for antibiotics has been confirmed, it is crucial to identify or deduce the infectious agent based on characteristic signs of infections and the epidemiological data available. Upon establishing or deducing the etiologic agent, the drug must be selected based on history of bacterial and pharmacokinetic sensitivity, as well as on the most appropriate posological scheme (dose and length of treatment) that guarantees minimum inhibitory or bacterial concentrations at the infected site (Tavares, Penteado Filho, 2007).

After correct selection of the agent and proper election of the posological scheme, it remains of utmost importance that the patient be aware of the need to fully comply with the prescribed treatment and that failure to do so through early abandonment, forgetting of doses etc. will lead to treatment failure. It is important to bear in mind that failures in antimicrobial therapies call for new treatments and lead to the emergence of increasingly more resistant microorganisms, in turn requiring new diagnostic procedures and in some cases surgical management or/and hospital admission.

It is fundamental that the patient or caregiver recognizes the importance of adhering to the prescribed treatment. To raise this awareness, patient and caregiver must be informed on all aspects of their treatment: the associated etiological agent, the pathology caused and particularly, the treatment to be employed - drug, dose, interval between doses and length of treatment course (Kardas, 2002).

Well-informed patients become jointly responsible for the treatment, understanding their obligations and as- suming their share of responsibility for the success of the treatment, thereby significantly increasing the likelihood of a successful outcome of antimicrobial treatment (Vree et al., 2007).

A program run in Sweden since 1992 - "the Swedish Strategic Programme for the Rational Use of Antimicrobial Agents and Surveillance of Resistance (STRAMA)" - had the goal, within its first year of operation, of rationalizing antimicrobial use in children aged less than five years infected by pneumococcus. Educational campaigns targeting medical practitioners, parents and pharmacists highlighted the importance of the quality of prescriptions and the correct use of antimicrobials. The campaign resulted in a $22 \%$ drop in antimicrobial prescriptions, i.e. a fall in number of DDD dispensed (DDD [defined daily dose]/100 inhabitants) from 16.3 to 13.0. The most interesting finding in this intervention program was the reduced incidence of resistant microorganisms accompanying the lower consumption of these medicines (Molstad, Cars, 1999).

A similar study was carried out in Massachusetts (USA) determining the level of knowledge among parents on microbiotic use and subsequently assessing the impact of an educational action on information levels. Approximately 200 couples took part in the study. The results indicated that, independent of social class, the initial level of information on antimicrobials was extremely low. After initial assessment, couples were divided into two groups. One of the groups received a handout and educational videotape on antimicrobial use. After one month both groups answered a similar questionnaire. The group which underwent the educational action answered $67 \%$ of the questions correctly versus $34 \%$ in the non-intervention group. These results emphasized that a simple intervention was able to substantially increase the level of information held by participants and consequently fostered more rational use of antimicrobials (Howard et al., 2001).

Another action along the same lines was performed in Belgium in 2000 - A public campaign for a more rational use of antibiotics. This campaign entailed an initial assessment in the level of information held by the population and among health professionals directly involved in antimicrobial use. Results showed that up to $83 \%$ of the population surveyed believed that use of antimicrobials led to swifter cure of influenza and/or common colds, revealing a high degree of misconception on the matter (Bauraind et al., 2004).

Given that information on the use of medicines is an integral part of successful antimicrobial treatment, the aim of this study was to ascertain the level of information held by antibiotic users on the treatment they were undergoing. 


\section{MATERIAL AND METHODS}

This study involved an exploratory survey using standardized interviews via structured questionnaires using the Access ${ }^{\circledR}$ database.

The assessment instrument was applied over a 12-month period in 2006 by three researchers holding grants under the Scientific Initiation program of Sorocaba University at three different sites: Community Pharmacy "Vital Brazil" (Training School Pharmacy) providing a pharmacy service and free medicines to the public; $b$ ) Basic Health Unit Pharmacy (Public) situated in the central region of the municipal district of Sorocaba; c) Commercial Pharmacy, also located in the city center.

Users who were present at the above data collection sites with medical or dental prescriptions containing one of more antibiotics answered the questionnaire. In the case of users under the age of 18 years, the questionnaire was answered by their accompanying guardian. Health professionals were excluded from the study.

The instrument comprised 70 questions gathering information on: (i) the patient (profile and habits); (ii) the prescription and the consultation; (iii) the clinical condition which led the patient to seek medical attention; and (iv) the level of information held by the user concerning the use of antibiotics. The $\mathrm{Z}$ test, at a $5 \%$ level of significance, was used to compare proportions of resulting data.

The present study was submitted to and approved by the Research Ethics Committee of the Center for Biological and Medical Sciences of Sorocaba - PUC/SP. The questionnaire was validated and adapted through a pilot project applied in antibiotic users.

\section{RESULTS AND DISCUSSION}

A total of 403 antibiotic users took part in the study. One hundred volunteers answered the questionnaire at the Basic Health Unit, 114 at the Commercial Pharmacy and 189 at the School Pharmacy. In terms of educational level of the interviewees, $43.38 \%$ of participants were educated to elementary level. No significant difference $(p>0.05)$ in number of individuals without schooling was found among the three data collection sites. Comparing only individuals with elementary education, a higher proportion was registered at the School Pharmacy (70.37\%), followed by the Basic Health Unit (38.00\%) with the lowest proportion being interviewees at the Commercial Pharmacy $(\mathrm{p}<0.05)$ (Figure 1). Regarding interviewees with University-level education, no statistically significant difference was found between the Basic Health Unit (10.00\%) and the Commercial Pharmacy (17.54\%). A difference in proportion of individuals with University education was found only between interviewees at the School Pharmacy and those at the Commercial Pharmacy. It should be noted however, that this data reflects the educational level of those responsible for administering the medicines and not necessarily the schooling level of users.

These data revealed the highest educational level was among patients seen at the Commercial Pharmacy, followed by those at the Basic Health Unit, and lastly the interviewees at the School Pharmacy.

In order to attain successful antimicrobial treatment, besides the right choice of medicine and posology, full adherence is required of the patient. This entails that the patient understand the prescription and the treatment

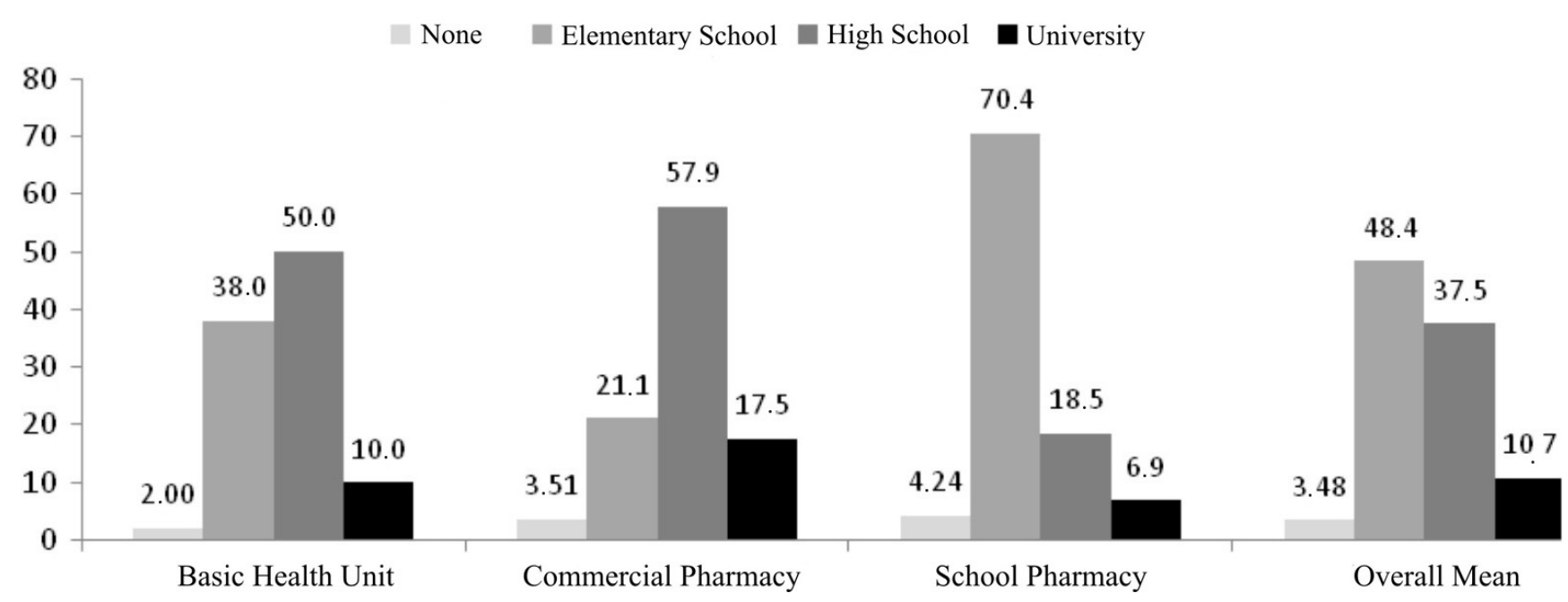

FIGURE 1 - Educational level of antibiotic users - Sorocaba, São Paulo State. 2006. 
TABLE I - Ability to read prescription, and level of information received during consultations in antibiotic users - Sorocaba, São Paulo State. 2006.

\begin{tabular}{lccc}
\hline Educational Level & Name of Medicine & Posological Regimen & Received No information \\
& $\mathrm{N}(\%)^{*}$ & $\mathrm{~N}(\%)$ & $\mathrm{N}(\%)$ \\
\hline University & $34(79.0) \mathrm{a}^{* *}$ & $36(83.7) \mathrm{a}$ & $3(6.9) \mathrm{a}$ \\
High School & $107(70.8) \mathrm{a}$ & $97(64.2) \mathrm{b}$ & $11(7.2) \mathrm{a}, \mathrm{b}$ \\
Elementary School & $109(55.8) \mathrm{b}$ & $114(58.4) \mathrm{b}$ & $47(24.1) \mathrm{b}, \mathrm{c}$ \\
None & $3(21.4) \mathrm{c}$ & $4(28.5) \mathrm{c}$ & $4(28.5) \mathrm{c}$ \\
\hline
\end{tabular}

* Percentages refer to relative educational level. ** Different letters indicate difference at $5 \%$ level of significance

adopted. To investigate this aspect, users were asked to read out the name of the medicine and the posological regimen from prescriptions. Additionally, users were asked whether they had been given any guidance on how to use the medicine provided, during their consultations. Results are shown in Table 1.

Results in Table I show a greater difficulty in understanding the prescription among those with little or no schooling ( $\mathrm{p}<0.05)$ where only $21.4 \%$ of this group managed to read the name of the medicine and $28.5 \%$ read and understood the prescribed posological regimen. Another interesting finding was that the same group (no schooling) received the least information on how to use the medicine, during the consultation.

Moreover, greater years of schooling did not guarantee better understanding of the prescription, since $70.8 \%$ high-school educated users managed to read the name of the medicine and $64.2 \%$ understood the posological regimen. These understanding levels rose to 79.0 and $83.7 \%$ for prescription and regimen among university-educated individuals. This data indicates that being literate is insuf- ficient to ensure full understanding of prescriptions. The ideal clear and comprehensive guidance to be followed for a successful course of treatment becomes inaccessible for a large proportion of the population.

With regard to verbal information given during the consultation, it is notable that patients with the lowest educational level are those who most frequently report not having received information on the use of medicines, during the consultation. This group has problems understanding the prescription yet do not feel at ease to ask questions. Such patients should be encouraged to ask health professionals about the most basic of doubts over use of medicines.

Concerning the posological scheme adopted, patients educated to university or high-school level received more information than elementary-educated patients or those with no formal schooling $(\mathrm{p}<0.05)$. The same pattern was found for information on length of course, albeit reaching significance only between groups with university-level education and those with no schooling $(p<0.05)$. These results are depicted in Figure 2.

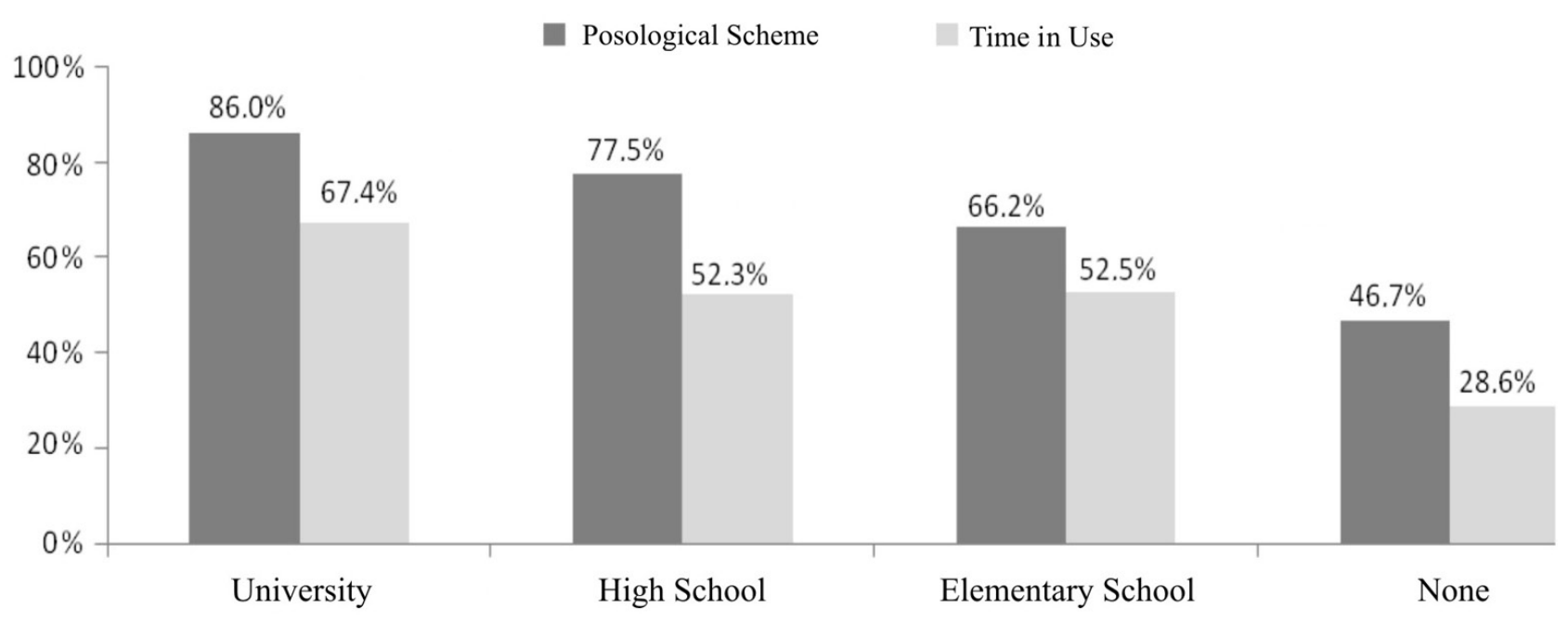

FIGURE 2 - Verbal information received during the consultation by educational level of user. 
TABLE II - Correct answers regarding use of antibiotics.

\begin{tabular}{lcc}
\hline Educational Level & Reported knowing purpose of antibiotics & Correct Answers \\
& $\mathrm{N}(\%)$ & $\mathrm{N}(\%)$ \\
\hline University & $30(69.7) \mathrm{a}, \mathrm{c}$ & $25(58.1) \mathrm{a}$ \\
High-School & $122(80.8) \mathrm{b}, \mathrm{c}$ & $63(41.7) \mathrm{a}$ \\
Elementary School & $170(87.1) \mathrm{b}$ & $107(54.8) \mathrm{a}$ \\
None & $8(57.1) \mathrm{a}$ & $5(35.7) \mathrm{a}$ \\
Total & $\mathbf{3 3 0}(\mathbf{8 1 . 9 )}$ & $\mathbf{2 0 1}(\mathbf{4 9 . 8 )}$ \\
\hline
\end{tabular}

* Percentages presented refer to relative educational level. ** Different letters indicate difference at $5 \%$ level of significance

The present study also included questions to antibiotic users verifying whether they knew the purpose of this class of medicines. Those who answered positively were then asked what the function of these medicines were, or in layperson's language, "what are antibiotics for?". The answers were assessed individually and results are shown in Table II.

Examination of the data in Table II reveals that users with high-school (80.8\%) and elementary (87.1\%) education differed from the other groups $(\mathrm{p}<0.05)$ in stating that they "knew what antibiotics were for". Upon being asked what the purpose of antibiotics was, the level of information held by users on the actual use of antibiotics was found to bear no relation to their level of schooling, in contrast with results for prescription reading and information received during consultations. No statistically significant difference $(p>0.05)$ regarding correct answers was detected among the groups studied. Notably, half of the population studied (49.8\%) did not know or had misconceptions about the true use of this class of medicines.

A key item of information concerning antimicrobial treatment involves full completion of the prescribed course of treatment. Treatment is commonly discontinued due to side effects, resolution of symptoms or the belief that continued administration of the medicine could be harmful. In view of this, users were asked about length of time in use of the prescribed antibiotic. The results are shown in Table III.

In a recent study (Clionda et al., 2007), the authors used the same line of questioning with antibiotic users and found an $88.7 \%$ level of complete adherence, similar to the results of the present study $(81.6 \%)$. In response to the question inquiring why they had abandoned treatment, $65 \%$ of patients in the cited study stated they had stopped using the medicine because they had "felt better". In the present study, overall $11.4 \%$ of users studied reported improved condition as the reason for discontinuing treatment (61.9\% of users who abandoned treatment).

The data shown in Table III shows that users with no schooling had the lowest adherence (57.1\%) to prescribed treatment. Also noteworthy is the finding that a high proportion of users with no formal schooling $(21.4 \%)$ "abandoned" treatment early because symptoms disappeared.

In order to ascertain the level of knowledge held by antibiotic users on the use of these medicines, the present study put 14 statements on the use of antibiotics to users. After hearing the statements, users had to rate them from 1 to 5 according to their degree of agreement with the statement: if completely agreeing with the statement they had to give a rating of 5 and if completely disagreeing a rating of 1 . Partial agreement was scored as 4 , partial disagreement as 2 and when users had no knowledge on the matter the score assigned was 3 .

TABLE III - Percentage distribution of time in use of antibiotic by educational level.

\begin{tabular}{lcccc}
\hline & $\begin{array}{c}\text { Until finishing flask/ } \\
\text { tablet blister }\end{array}$ & $\begin{array}{c}\text { Until symptom } \\
\text { resolution }\end{array}$ & $\begin{array}{c}\text { Until interruption } \\
\text { due to side effects }\end{array}$ & $\begin{array}{c}\text { Until end of } \\
\text { indicated course }\end{array}$ \\
\hline University & $7.0 \%$ & $16.3 \%$ & $0.0 \%$ & $76.7 \% \mathrm{a}, \mathrm{b}$ \\
High-School & $3.3 \%$ & $7.9 \%$ & $2.0 \%$ & $86.8 \% \mathrm{a}$ \\
Elementary School & $6.2 \%$ & $12.3 \%$ & $1.0 \%$ & $80.5 \% \mathrm{a}$ \\
None & $14.3 \%$ & $21.4 \%$ & $7.1 \%$ & $57.1 \% \mathrm{~b}$ \\
Total & $\mathbf{5 . 5 \%}$ & $\mathbf{1 1 . 4 \%}$ & $\mathbf{1 . 5 \%}$ & $\mathbf{8 1 . 6 \%}$ \\
\hline
\end{tabular}

* Percentages presented refer to relative educational level. ** Different letters indicate difference at $5 \%$ level of significance 
CHART 1 - Statements presented to antibiotic users.

$1 \quad$ Children take a lot of antibiotics even when they don't need to.

2 Parents should not ask doctors to prescribe antibiotics for their children

3 Doctors should not prescribe antibiotics when they are not necessary.

4 Overuse of antibiotics can make bacteria resistant and the antibiotic can lose effect

5 The use of antibiotics and contraceptive pills can reduce the effect of the pill and women can become pregnant

$6 \quad$ Not all fevers need antibiotics

$7 \quad$ Antibiotics are used against diseases caused by bacteria

8 When a person with the flu takes an antibiotic it prevents other infections from emerging

9 After 5 days with flu it is important to take an antibiotic

10 In cases of flu, if nasal secretion changes from yellow to greenish then it's time to take an antibiotic

11 Antibiotics help to clear up flu more quickly

12 Antibiotics should be taken with milk as they are harmful to the stomach

13 Antibiotics ruin your teeth

14 Antibiotics are used against diseases caused by virus

Chart 1 lists the statements made to antibiotic users. The first seven statements (1 to 7) are true and the last seven ( 8 to 14) false. It should be emphasized that the statements were read out in random order. After giving each answer, users were provided with information on the statements and doubts were clarified.

Examination of the data contained in Figure 3 reveals that for the true statements ( 1 to 7 ) on which a score of 5 is expected, users scored five for all these statements (median) with the exception of statement 1 (median 4) and statement 5 (median 3). Statement 5 addresses concomitant use of oral contraceptives (pills) and antibiotics. The literature describes this same interaction, confirming that the population generally does not know this information
(Hindmarch, Oakeshott, 2002; Weaver, Glasier, 1999).

To obtain a profile of those users who specifically are unaware of this information (statement 5), the data pertaining to the statement was broken down into men and women respondents in this study and then compared using descriptive analysis. Although men and women had the same median score (3.0), the arithmetic mean of the men was slightly higher than that of women $(3.25$ versus 3.14 , respectively). No statistical difference was found between groups $(\mathrm{p}=0.373)$.

In relation to false statements $(8-14)$ for which expected score were 1 , a greater lack of knowledge was observed on statements 12 (median 4 and mean 3.49), 13 (median 5, mean 4.05) and 14 (median 4, mean 3.41).

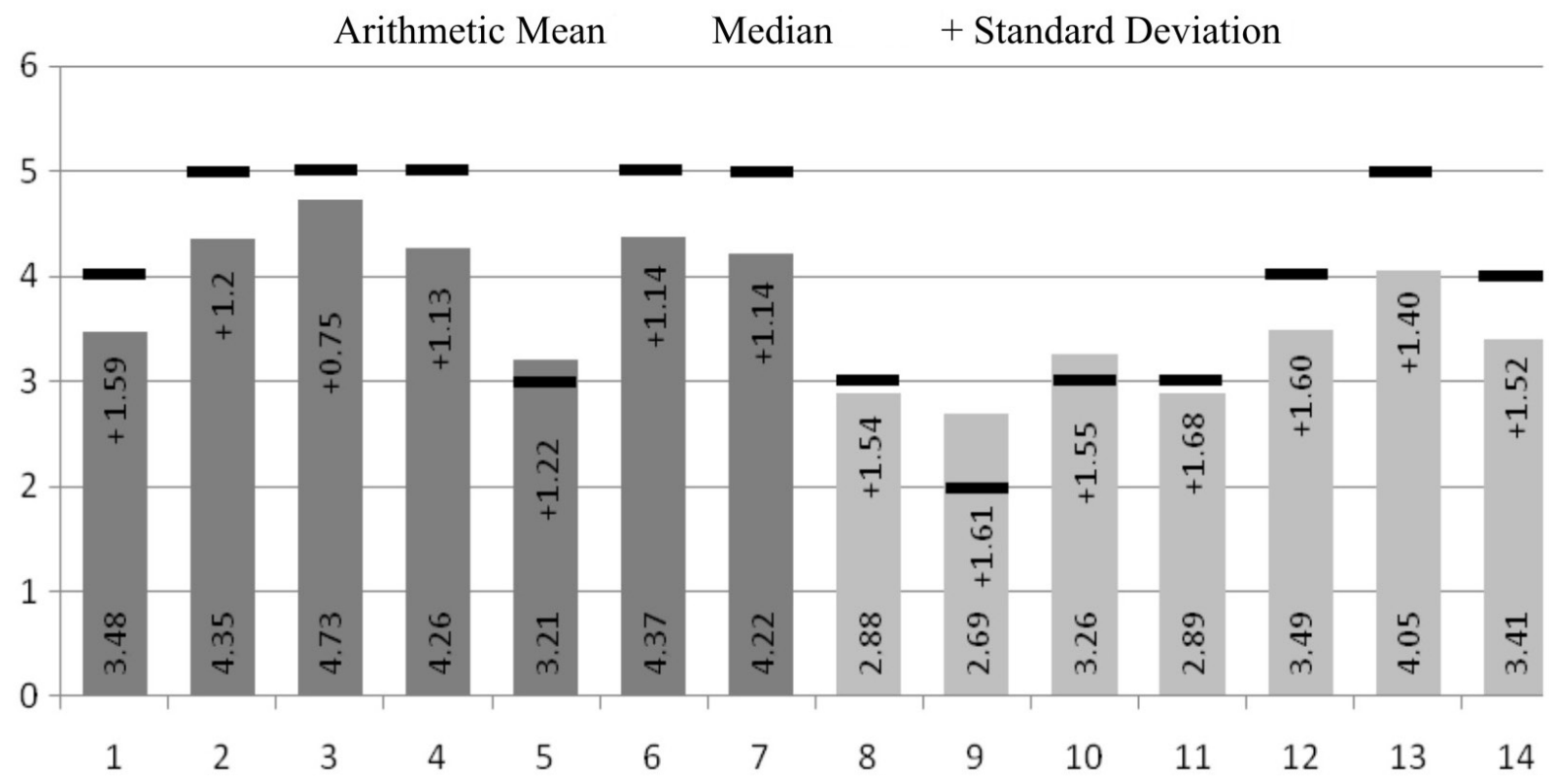

FIGURE 3 - Distribution of arithmetic mean, median and standard deviation of statements presented to antibiotic users. 
The worst result among false statements was for question 13 stating that antibiotics "ruined your teeth". The population generally believed that antibiotics can "weaken your teeth", and this represented a significant reason for abandonment of treatment particularly among children. The literature shows that only tetracycline administered to pregnant women and children aged between 0 and 8 years, can in fact lead to the appearance of brownish stains on teeth, changing their esthetic appearance but not their functionality or state of health (Del Fiol et al., 2005). The belief that all antibiotics cause dental problems is a major factor contributing to early abandonment of pediatric treatment because after disappearance of pain and fever symptoms parents' first reaction is to suspend antimicrobial treatment in the belief that they are safeguarding the dental health of their children.

With regard to statement 14, a large proportion of users (26.3\% [data not shown]) believed these medicines can act on diseases caused by virus. In the study by Clionda et al (2007), this proportion reached $38 \%$.

Studies on information regarding use of medicines are scarce in the literature, particularly for antibiotics, pointing to a need for further studies in this area.

\section{CONCLUSIONS}

The level of information held by the antibiotic users interviewed in this study can be deemed insufficient to ensure correct use of these medicines, given that a high percentage of users reported not having received information during the medical consultation. Around $20 \%$ were unable to read the name of the medicine. In terms of posology, the same proportion reported not complying fully with the treatment. These results also demonstrate a lack of awareness on the purpose of antibiotics, in addition to beliefs which negatively impact treatment. Although users with greater schooling level had more knowledge on antibiotics, significant information deficits were also identified in this group. Furthermore, users with lower educational level reported receiving less information during medical consultations.

\section{REFERENCES}

BAURAIND, I.; LOPEZ-LOZANO, J.M.; BEYAERT, A.; MARCHAL, J.L.; SEYS, B.; YANE, F.; HENDRICKX, E.; GOOSSENS, H.; TULKENS, P.M.; VERBIST, L. Association between antibiotic sales and public campaigns for their appropriate use. JAMA, v.292, n.20, p.2468-2470, 2004
CLIONDA, A.M.; BOYLE, P.; NICHOLS, T.; CLAPPISON, P.; DAVEY, P. Don't wear me out the public's knowledge of and attitudes to antibiotic use. J. Antimicrob. Chemother. v.59, n.4, p.727-738, 2007.

DEL FIOL, F.S.; GERENUTTI, M.; GROPPO, F.C. Antibiotics and pregnancy. Pharmazie, v.60, n.7, p.483-493, 2005.

DEL FIOL, F.S.; MATTOS-FILHO, T.R.; GROPPO, F.C. Resistência bacteriana. Rev. Bras. Med., v.57, n.10, p.11291140,2000

HINDMARCH, M.; OAKESHOTT, P. Interactions of the oral contraceptive pill with antibiotics and St John's wort: knowledge of female college students. Fam. Pract., v.19, n.6, p.708, 2002.

HOWARD B.; STAVROULA, O.; KEVIN, S.; RANDI, T. Improving parent knowledge about antibiotics: a video intervention. Pediatrics, v.108, n.4, p.845-850, 2001.

KARDAS, P. Patient compliance with antibiotic treatment for respiratory tract infections. J. Antimicrob. Chemother, v.49, n.6, p.897-903, 2002.

LADD, E. The use of antibiotics for viral upper respiratory tract infections: an analysis of nurse practitioner and physician prescribing practices in ambulatory care, 1997-2001. J. Am. Acad. Nurse Pract., v.17, n.10, p.416-424, 2005.

MARRA, F.; PATRICK, D.M.; CHONG, M.; BOWIE, W.R. Antibiotic use among children in British Columbia, Canada. J. Antimicrob. Chemother., v.58, p.830-839, 2006.

MOLSTAD, S., CARS, O. Major change in the use of antibiotics following a national programme: Swedish strategic programme for the rational use of antimicrobial agents and surveillance of resistance (STRAMA). Scand. J. Infect. Dis., v.31, n.2, p.191-195, 1999.

RYBAK, M.J. Pharmacodynamics: relation to antimicrobial resistance. Am. J. Infect. Control., v.34, n.5, p.38-45, 2006.

TAVARES, W.; PENTEADO FILHO, S.R. Antimicrobianos: critérios para o uso racional na prática clínica. In: TAVARES, W.; MARINHO, L.A. Rotinas de diagnóstico e tratamento das doenças infecciosas e parasitárias. 2.ed. São Paulo: Atheneu, 2007. p.1048-1062. 
VREE, M.; HUONG, N.T.; DUONG, B.D.; SY, D.N.; VAN, L.N.; CO, N.V.; COBELENS, F.G.J.; BORGDORFF, M.W. Mortality and failure among tuberculosis patients who did not complete treatment in Vietnam: a cohort study. $B M C$ Public Health, v.7, n.134, p.1-8, 2007.

WEAVER, K.; GLASIER, A. Interaction between broadspectrum antibiotics and the combined oral contraceptive pill. A literature review. Contraception, v.59, n.2, p.71-75, 1999.
WORLD HEALTH ORGANIZATION. Emerging and other communicable diseases: antimicrobial resistance. World Health Assembly Resolution, WHA 51.17. Geneve, 1998. p.1-2.

Received for publication on $10^{\text {th }}$ November 2008 Accepted for publication on $25^{\text {th }}$ February 2010 